\title{
Germline mutations of the INK4a-ARF gene in patients with suspected genetic predisposition to melanoma
}

\author{
N Soufir,', JJ Lacapere', G Bertrand', E Matichard', R Meziani', D Mirebeau ${ }^{3}$, V Descamps ${ }^{4}$, B Gérard',

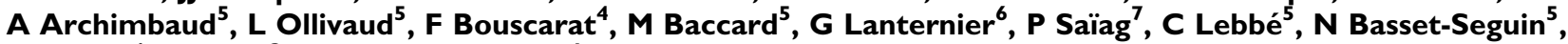 \\ B Crickx ${ }^{4}, \mathrm{H}$ Cave $^{3}$ and B Grandchamp' \\ 'Laboratoire de Biochimie Hormonale et Génétique, Hôpital Bichat-Claude Bernard, 46 rue henri Huchard, Paris 75018 , France; ${ }^{2}$ Inserm U 410 Faculté \\ Bichat-Claude Bernard, Paris 75018 , France; ' ${ }^{3}$ aboratoire de Biochimie-Génétique, Hôpital Robert Debré, Paris 750 I 8, France; ${ }^{4}$ Dermatology \\ Department, Hôpital Bichat-Claude Bernard, Paris 75018 , France; ${ }^{5}$ Dermatology Department, Hôpital Saint-Louis, Paris 750 I0, France; ${ }^{6}$ Dermatology \\ Department, Hôpital Percy, Clamart 92140 . France; ' Dermatology Department, Hôpital Ambroise Paré, 92 Boulogne Billancourt, France
}

Germline anomalies of the INK4a-ARF and Cdk4 genes were sought in a series of 89 patients suspected of having a genetic predisposition to melanoma. Patients were selected based on the following criteria: (a) familial melanoma (23 cases), (b) multiple primary melanoma (MPM; 18 cases), (c) melanoma and additional unrelated cancers ( 13 cases), (d) age at diagnosis less than 25 years (2I cases), and (e) nonphoto-induced melanoma (NPIM; I 4 cases). Mutations of INK4a-ARF and Cdk4 were characterised by automated sequencing, and germline deletions of INK4a-ARF were also examined by real-time quantitative PCR. Seven germline changes of INK4a-ARF, five of which were novel, were found in seven patients (8\%). Four were very likely to be pathogenic mutations and were found in three high-risk melanoma families and in a patient who had a pancreatic carcinoma in addition to melanoma. Three variants of uncertain significance were detected in one MPM patient, one patient $<25$ years, and one NPIM patient. No germline deletion of INK4a-ARF was found in 7 I patients, and no Cdk4 mutation was observed in the 89 patients. This study confirms that INK4a-ARF mutations are infrequent outside stringent familial criteria, and that germline INK4a-ARF deletions are rarely involved in genetic predisposition to melanoma.

British Journal of Cancer (2004) 90,503-509. doi:I0.1038/sj.bjc.660I503 www.bjcancer.com

(c) 2004 Cancer Research UK

Keywords: INK4a-ARF; Cdk4; melanoma genetics; germline mutation; deletion

Familial melanomas comprise from 8 to $12 \%$ of all cutaneous malignant melanoma cases (Greene, 1999). Two highly penetrant melanoma-predisposing genes have been identified to date, INK4a$A R F$ and Cdk4 (Hussussian et al, 1994; Kamb et al, 1994; Zuo et al, 1996).

The INK4a-ARF gene on chromosome 9p21 encodes two structurally distinct tumour-suppressor proteins by virtue of different $5^{\prime}$ exons spliced in different reading frames to common exons 2 and 3. Exons $1 \alpha, 2$, and 3 encode p16 $6^{\mathrm{INK} 4 a}$, while exon $1 \beta$, spliced to exons 2 and 3 in a different reading frame and transcribed using a different promoter, encodes $\mathrm{p} 14^{\mathrm{ARF}}$ protein (ARF, also called $\mathrm{p} 19^{\mathrm{ARF}}$ in mice). $\mathrm{P} 16^{\mathrm{INK} 4 a}$ is part of the $\mathrm{G} 1-\mathrm{S}$ cell cycle checkpoint mechanism that involves the retinoblastomasusceptibility tumour suppressor protein (pRB). PRB protein, in its unphosphorylated state, inhibits the progression of the cell cycle from the $\mathrm{G} 1$ to the $\mathrm{S}$ phase by sequestering the transcription factor E2F1. Phosphorylation of pRB by the cyclin-dependent-kinases CDK4 and 6 (CDK4-6/D kinases) releases E2F1 and allows progression through the $\mathrm{G} 1-\mathrm{S}$ checkpoint. $\mathrm{P} 16^{\mathrm{INK} 4 a}$ is a specific

*Correspondence: N Soufir; E-mail: nadem.soufir@bch.ap-hop-paris.fr Contract Grant sponsor: AP-HP; Contract Grant number: CRCOOI28 Received 15 May 2003; revised 30 September 2003; accepted 22 October 2003 inhibitor of CDK4 and 6, and thus, inactivation of $\mathrm{p} 16^{\mathrm{INK} 4 a}$ allows cells to escape cell cycle arrest in G1.

The other product of the INK4a-ARF locus, p14 ${ }^{\mathrm{ARF}}$, also acts as a tumour suppressor (Sherr, 2000). Mice lacking ARF, but with intact $\mathrm{p} 16^{\mathrm{INK} 4 a}$, develop tumours (Kamijo et al, 1997), while transfection of ARF into some carcinoma cell lines results in marked growth inhibition (Simon et al, 1999; Yang et al, 2000). ARF mediates G1 and G2 arrest at least partly by its interaction with MDM2, a protein that binds to both TP53 and pRB. MDM2 targets TP53 for degradation by ubiquitination (Ashcroft and Vousden, 1999) and also inhibits pRB growth-regulatory function. ARF binds to MDM2 and promotes its degradation (Pomerantz et al, 1998; Zhuang et al, 1998), resulting in stabilisation and accumulation of TP53 protein and also of its downstream target p21, an inhibitor not only of CDK4 and 6 but also of other CDKs.

Multiple studies have shown that germline mutations in the INK $4 a-A R F$ gene are found on average in approximately $25 \%$ of melanoma-prone families (reviewed in (Hayward, 2000; Piepkorn, 2000). The frequency of INK4a-ARF mutations in melanoma probands increases with (i) the number of affected relatives, (ii) the presence of multiple melanomas in the same patient, (Soufir et al, 1998a; Holland et al, 1999) and (iii) a history of pancreatic cancer cases in the family (Goldstein et al, 1995).

In contrast, mutations of $C d k 4$ appear to be a rare cause of inherited susceptibility to melanoma. Four germline alterations 
have been described in $C d k 4$ to date, in four melanoma-prone kindreds (Zuo et al, 1996; Soufir et al, 1998a; Holland et al, 1999) and in one melanoma patient with no known family history (Guldberg et al, 1997). Two mutations occur in exon 2 of $c d k 4$ at the same codon (Arg24Cys, Arg24His) and functional analysis of the Arg24Cys mutant protein reveals that it is deficient in binding to $16^{\mathrm{INK} 4 a}$, but is capable of binding cyclin D and phosphorylating pRB.

Whereas germline mutations in the INK4a-ARF gene are uncommon in unselected melanoma patients from the general population (Aitken et al, 1999), the prevalence of INK4a-ARF mutations in patients suspected of having a genetic predisposition to melanoma outside a familial context remains to be clarified.

Therefore, in this work, we hypothesise that in addition to patients with familial melanoma, some patients could have an inherited predisposition to melanoma and might harbour germline mutations of INK4a-ARF. These patients include those who had multiple primary melanomas (MPM), melanoma associated with another cancer, melanoma developing at a young age, or nonphoto-induced melanomas (NPIM).

This hypothesis is strengthened by the fact that germline mutations of the INK4a-ARF gene have been detected in some MPMs (MacKie et al, 1998; Monzon et al, 1998; Hashemi et al, 2000; Auroy et al, 2001), and could also predispose to other types of cancers, such as pancreatic cancer (Borg et al, 2000), epidermoid carcinoma (Yarbrough et al, 1996), breast cancer (Borg et al, 2000), or multiple myeloma (Dilworth et al, 2000) in melanoma families.

The proposition that patients who develop melanoma at a young age harbour a strong predisposition to melanocyte neoplasia is consistent with Knudson's hypothesis that cancers arising at a very young age may result from mutations to key regulatory genes passed through the germline model for the incidence of retinoblastoma. Finally, melanomas considered to be nonphotoinduced (NPIM) include (i) melanomas located on nonphotoexposed sites (sun-protected skin areas or mucous localisations) and (ii) subungual and acral lentiginous melanomas that are considered to be particular subtypes of melanoma, because, in contrast to other subtypes, ultraviolet irradiation is not a major factor in their development (Kato et al, 1996; Saida, 2001), thus suggesting genetic factors in their onset.

Therefore, the specific aim of this study was to assess the prevalence of INK4a-ARF and Cdk4 mutations among different subgroups of patients with a possible hereditary predisposition to melanoma. Here, we report that INK4a-ARF mutations are predominantly found in high-risk melanoma kindreds, confirming previous reports. However, we also found that INK4a-ARF mutations are rarely present in individuals with suspected genetic predisposition to melanoma (MPM, melanoma arising before the age of 25 years, NPIM) without a family history of melanoma.

\section{PATIENTS AND METHODS}

\section{Selection of patients}

The present study was performed from 1999 to September 2002. Patients were enrolled at the Saint Louis (50\%), Bichat-Claude Bernard (45\%), Ambroise Paré (5\%), and Percy Hospitals (5\%), which are located in or near Paris city. In all, 89 patients were prospectively enrolled in the study, of which $10 \%$ were incident cases. The inclusion criteria were: (1) familial melanoma (FAM; 23 cases) defined as the presence of at least two melanoma cases in first- or second-degree relatives (all cases confirmed by pathological reports); (2) multiple primary melanomas (MPM) defined as the presence of at least two primary melanomas in the same patient confirmed by pathological reports (18 cases); (3) melanoma in young patients defined as melanoma in patients younger than 25 years (21 cases); (4) nonphoto-induced melanoma (14 cases) defined by either melanomas located on nonphoto-exposed sites (sun-protected skin areas or mucous localisations), and/or subungual and acral lentiginous melanomas, which are considered to be particular subtypes of melanoma; and (5) melanoma associated with another cancer (13 cases). For familial melanoma cases, only the proband was enrolled.

Written informed consent allowing peripheral blood sampling and genetic analysis was obtained for each patient enrolled in the study. Adoption and xeroderma pigmentosum cases were excluded.

For each patient included, clinical information was obtained by a dermatologist and from medical records: family history of melanoma, age at diagnosis of melanoma, tumour location, histopathological classification and Breslow thickness, diagnosis of multiple primary melanomas or other cancer, nevus count, and the presence of clinically atypical mole syndrome (AMS), defined as at least 50 nevi $>2 \mathrm{~mm}$ in diameter and including at least three atypical nevi.

\section{DNA PCR and sequencing}

Genomic DNA was extracted from peripheral blood lymphocytes as described by Miller et al (1988). The INK4a-ARF locus comprises four exons, coding for two alternative transcripts: p16 $6^{\mathrm{INK} 4 a}$ (exons $1 \alpha, 2$ and 3 ) and $\mathrm{p} 14^{\mathrm{ARF}}$ (exons $1 \beta, 2$ and 3 ). PCR was performed on 50-100 ng of extracted DNA using the following cycling conditions: 35 cycles at $94^{\circ} \mathrm{C}(30 \mathrm{~s}), \mathrm{Tm}$ at $62^{\circ} \mathrm{C}(30 \mathrm{~s})$ and $72^{\circ} \mathrm{C}(1 \mathrm{~min})$, and $10 \%$ DMSO (dimethylsulphoxide). The primer sequences for exons $1 \alpha, 1 \beta$, and 2 are listed in Table 1 . Coding and flanking intron sequences of exon 2 of the $C d k 4$ gene, which include residues previously shown to be mutated in familial melanoma (Zuo et al, 1996; Soufir et al, 1998b) were amplified using the primer pair Cdk4F1 and Cdk4R1 (Table 1).

The PCR products were purified with the PCR product presequencing kit according to the manufacturer's protocol. All fragments were sequenced with the Applied Biosystems (ABI) BigDye Terminator Cycle Sequencing Ready Reaction Kit according to the manufacturer's instructions, and sequencing reactions were analysed on an ABI 3100 automated sequencer.

\section{INK4a-ARF deletion analysis by real-time quantitative PCR}

INK4a-ARF deletion analysis was performed as recently described for the characterisation of mono- and biallelic 9p21 deletions in childhood acute lymphoblastic leukaemia (Bertin et al, 2003). Realtime quantitation was performed using the SYBR Green I dye as a fluorescent signal. The dye binds specifically to the minor groove

Table I PCR primers used for automated sequencing of INKA-ARF coding exons $(|\alpha,| \beta, 2,3)$ and $C d k 4$ exon 2

\begin{tabular}{|c|c|c|}
\hline $\begin{array}{l}\text { Primer } \\
\text { localisation }\end{array}$ & $\begin{array}{c}\text { Primer } \\
\text { name }\end{array}$ & Sequences $\left(5^{\prime}-3^{\prime}\right)$ \\
\hline \multicolumn{3}{|l|}{$\begin{array}{l}\text { Sequencing } \\
\text { primers }\end{array}$} \\
\hline \multirow[t]{2}{*}{$\begin{array}{l}\text { Exon } 1 \alpha \\
p \mid 6^{\text {INK4A }}\end{array}$} & $\mathrm{PI} 6 \mathrm{FI}$ & GCT CGG CGG CTG CGG AGA GG \\
\hline & PI6RI & TCC AGA GTC GCC CGC CAT CCC \\
\hline \multirow[t]{2}{*}{$\begin{array}{c}\text { Exon } 2 \\
\text { INK4a-ARF }\end{array}$} & PI6F2 & GGG TCT GCT TGG CGG TGA GG \\
\hline & $\mathrm{P} 16 \mathrm{R} 2$ & CGG GCT GAA CTT TCT GTG CTG GA \\
\hline \multirow[t]{2}{*}{$\begin{array}{l}\text { Exon I } \beta \\
\text { p } \mid 4^{\mathrm{ARF}}\end{array}$} & $\mathrm{P} \mid 4 \mathrm{FI}$ & TGC GTG GGT CCC AGT CTG CAG \\
\hline & $P|4 R|$ & ACC GCG GTG GAG GCT TCC CAT \\
\hline \multirow{2}{*}{$\begin{array}{l}\text { Exon } 2 \\
\text { Cdk4 }\end{array}$} & CDK4FI & GGA TGG GAT GCT GGT GGT GTT \\
\hline & CDK4RI & ТTC ССТ ТTA СТС ССС ACG CCC \\
\hline
\end{tabular}


of double-stranded DNA, allowing the detection of PCR product formation (Ginzinger, 2002).

Two targets were amplified on 9p21: $p 16^{I N K 4 a}$ exon 3 and $p 14^{A R F}$ exon $1 \beta$. One single-copy sequence was used as a reference sequence: 8q11 SST (Single Sequence Tag), mapping at 8q11. A volume of $5 \mu \mathrm{l}$ of DNA was added to the PCR reaction mixture containing $1 \times$ SYBR Green buffer (Applied Biosystems), $300 \mathrm{nM}$ forward and reverse primers, $5 \mathrm{~mm} \mathrm{MgCl}_{2}$ ( $3 \mathrm{~mm}$ for $8 \mathrm{q} 11 \mathrm{SST}$ ), $200 \mu \mathrm{M} \mathrm{dNTP}$, and $0.6 \mathrm{U}$ of AmpliTaq Gold (Applied Biosystems) in a final volume of $25 \mu \mathrm{l}$.

Each series of PCR reactions included two negative controls containing water in place of DNA, one control containing $15 \mathrm{ng}$ of HeLa DNA, and a five-point standard curve. The standard curve was established using serial dilutions of normal PBMC in Tris (10 mM)-EDTA (1 mM) buffer, ranging from 10 to $0.02 \mathrm{ng} \mu \mathrm{l}^{-1}$ (corresponding to $50 \mathrm{ng}$ to $0.1 \mathrm{ng}$ of DNA analysed per well). The same dilutions were used for all targets and reference sequences. PCR was performed on the ABI PRISM 7700 Sequence detector system (Applied Biosystems). All analyses were performed in duplicate. The PCR amplification profile was as follows: initial denaturation at $95^{\circ} \mathrm{C}$ for $10 \mathrm{~min}$, followed by 40 cycles of denaturation at $95^{\circ} \mathrm{C}$ for $10 \mathrm{~s}$, and combined annealing and extension at $65^{\circ} \mathrm{C}$ for $1 \mathrm{~min}$. Detection of the fluorescent product was carried out at the end of the extension period. To confirm amplification specificity, the PCR products from each primer pair were subjected to a melting-curve analysis and subsequent agarose gel electrophoresis. The concentration of each gene was calculated based on the respective calibration curve. The relative copy numbers of $p 16^{I N K 4 a}$ and $p 14^{A R F}$ were then obtained by calculating the ratio of the result obtained for each target to the 8q11 SST value. The normalised ratio of each target on 8q11 SST was expected to be close to 1 if no deletion was present. Childhood acute lymphoblastic leukaemia samples carrying somatic deletion at the INK4a-ARF locus were used as positive controls (Bertin et al, 2003).

\section{RESULTS}

\section{Patient characteristics}

Patients were categorised into five different melanoma subgroups: (a) familial melanoma (FAM, 23 cases), (b) multiple primary melanoma (MPM, 18 cases), (c) melanoma and additional unrelated cancers (13 cases), (d) age at diagnosis less than 25 years (21 cases), and (e) nonphoto-induced melanoma (NPIM, 14 cases). The numbers of patients in each group, median age at diagnosis, patient's nevus count, and the presence of AMS are listed in Table 2.

Of the 23 melanoma-prone families, two had four melanomaaffected members, five had three affected members, and 16 had two affected members. In all, 17 families had at least two first-degreerelated affected members, whereas the six remaining families had second-degree-related affected members. Five families (all with

Table 2 Characterisation of the different melanoma subgroups

\begin{tabular}{llcrrr}
\hline & MM subgroup & $\begin{array}{c}\text { Number of } \\
\text { patients }\end{array}$ & $\begin{array}{c}\text { Median age } \\
\text { at diagnosis }\end{array}$ & $\begin{array}{c}\text { Naevus } \\
\text { count }>\mathbf{5 0}\end{array}$ & AMS \\
\hline I & FAM & 23 & $43(18-74)$ & $11(48)$ & $4(17)$ \\
2 & MPM & 18 & $42(19-70)$ & $8(47)$ & $4(22)$ \\
3 & MM $<25$ years & 21 & $21(14-25)$ & $11(50)$ & $6(28)$ \\
4 & MM+other cancer & 13 & $54(27-76)$ & $3(27)$ & $1(8)$ \\
5 & NPIM & 14 & $58(42-73)$ & $4(28)$ & $1(7)$ \\
\hline
\end{tabular}

MM = malignant melanoma; FAM = melanoma families; $M P M=$ multiple primary melanoma; NPIM = nonphoto-induced melanoma. two first-degree-related affected members) comprised at least one member with multiple melanomas, and five families comprised one patient who developed a melanoma before the age of 25 years.

Among the 18 MPM cases selected, 14 developed two melanomas, and four developed three distinct melanomas. The median age for the onset of the first melanoma was 42 years (range 19-70).

In total, 14 patients had a melanoma classically considered not to be photo-induced (NPIM). Of these, three patients had a melanoma localised on the digestive tract (anal and colon, one and two patients, respectively). Four patients had a melanoma localised on the buttocks, and two had a melanoma localised on the genital organs. Four patients had an acrolentiginous melanoma, of which three were subungual, and one was located on the sole of the foot. One patient had a melanoma of the scalp.

Totally, 13 patients developed another cancer in addition to melanoma: seven patients had glandular carcinomas (mammary adenocarcinoma: three cases; thyroid carcinoma, one case; prostate carcinoma, one case; uterus carcinoma, one case; colon carcinoma, one case; pancreatic carcinoma, one case); four other patients developed multiple basal cell carcinomas; one patient had a meningioma.

\section{Mutational analysis of INK4a-ARF and Cdk4 genes}

In the present study, we identified two previously reported mutations in the INK4a-ARF gene and five novel INK4a-ARF mutations (Table 3).

Four mutations likely to be pathogenic were detected in three melanoma families and in a patient who had a pancreatic cancer in addition to melanoma.

The first mutation, present in a melanoma-prone family comprising three affected members (FAM1), is a $24 \mathrm{bp}$ insertion located at nucleotide 23 of the $p 16^{I N K 4 a}$ mRNA, and is believed to arise due to unequal crossing-over between the two $24 \mathrm{bp}$ repeats naturally present in the wild-type sequence. The result is the addition of eight (duplicated) aminoacids at the flexible $\mathrm{N}$ terminal end of the translated protein outside the ankyrin motifs, and has also been reported to not affect p16 $6^{\mathrm{INK} 4 a}$ activity (Monzon et al, 1998). The functional significance of this in-frame insertion is uncertain as it occurs outside of the ankyrin domains. However, it is noteworthy that it segregates with melanoma in four melanoma kindreds (two in Australia, one in the UK, and one in the United States) (Walker et al, 1995; Flores et al, 1997; Harland et al, 1997). In our case, the mutation is present in the unaffected mother of the proband, but unfortunately the other two melanoma-affected members (the grandmother and her mother) could not be tested because they are deceased.

Table 3 INK4a-ARF germline mutations characterised in melanoma patients

\begin{tabular}{|c|c|c|c|c|}
\hline Patients & $\begin{array}{l}\text { MM } \\
\text { subgroup }\end{array}$ & $\begin{array}{l}\text { INK4a-ARF } \\
\text { mutation }\end{array}$ & $\begin{array}{l}\text { Effect on } \\
\text { p/6 }\end{array}$ & $\begin{array}{c}\text { Effect on } \\
\text { pl4 } 4^{\text {ARF }}\end{array}$ \\
\hline I & FAM & Ins 24 bp exon $1 \alpha$ & Duplication & - \\
\hline 2 & FAM & $C_{c}>c \mathbf{G}_{c}$ & Pro70Arg & Ala84ala \\
\hline 3 & FAM & $\mathbf{A} c t>\mathbf{C}_{c t}$ & Thr77Pro & His9 I Pro \\
\hline 4 & $M M+K$ pancreas & ${ }_{g} \mathbf{C}_{c}>g \mathbf{T}_{c}$ & Ala57Val & Arg7।Arg \\
\hline 5 & $M M<25$ years & $\mathrm{Ga} \mathbf{C}>\operatorname{ga} \mathbf{T}$ & Asp I05Asp & Argl 20 Cys \\
\hline 6 & MPM & $\mathbf{G} c g>\mathbf{A} c g$ & Ala5Thr & - \\
\hline 7 & NPIM & $\begin{array}{l}\mathrm{a} \mathbf{C} \mathrm{a}>\mathrm{a} \mathbf{T} \mathrm{a} \\
-25 \text { bp atg ex } \mid \alpha\end{array}$ & nd & - \\
\hline
\end{tabular}

The sequence is written as $5^{\prime} \rightarrow 3^{\prime}$ for the coding strand; the mutated base is written in uppercase letter. The text in bold indicates nucleotide and amino-acid changes. Abbreviations: Ins $=$ insertion; $M M=$ malignant melanoma; $F A M=$ familial melanoma; $M P M=$ multiple primary melanoma; NPIM = nonphoto-induced melanoma; n.d. $=$ not determined; $-=$ no effect 


$\begin{array}{ll}\text { P16 } & 1 \\ \text { P19 } & 1 \\ \text { P18 } & 1 \\ \text { P15 } & 1 \\ \text { P16 } & 38 \\ \text { P19 } & 35 \\ \text { P18 } & 31 \\ \text { P15 } & 39 \\ \text { P16 } & 70 \\ \text { P19 } & 67 \\ \text { P18 } & 63 \\ \text { P15 } & 71 \\ \text { P16 } & 104 \\ \text { P19 } & 100 \\ \text { P18 } & 96 \\ \text { P15 } & 105 \\ \text { P19 } & 134 \\ \text { P18 } & 130\end{array}$

MEPAAGSSMEPSADWLATAAARGRVEEVRALLEAG-AL MULEEVRAGDRLSGAAARGDVQEVRRLLHRELVH MAEPWGNELASAAARGDLEQLTSLLQNN - VN MREENKGMPSGGGSDEGLATPARGLVEKVRHSWEAG-AD

PN-APNSYGRRPIQVM-MMGSARVAELLLLHG-AE PD-ALNRFGKTALQVM-MFGSTAIALELLKOG-AS VN-AQNGFGRTALQVM-KLGNPEIARRLLLRG-AN PN-GVNRFGRRAIQVM-MMGSARVAELLLLHG-AE PN NVOD-TIGTSPVHDAARTGELDTLKVLVEHG-AD DD- I GAVIHDAARAGIDTLOTL PNCADPAT LTRPVHDAAREGFLDTLVVLHRAG-AR

LDVRD - AWGRLPVDLAEELGHRDVARYLRAAAGGT VNVPD-GTGALPIHLAVQEGHTAVVSFLAAESDLH VNIED-NEGNLPLHLAAKEGHLRVVEFLVKHTASN LDVRD-AWGRLPVDLAEERGHRDVAGYLRTATGD

-RRD-ARGLTPLELALQRGAQDLVDILQGHMVAPL VGHRN-HKGDTACDLARLYGREVVSLMQANGAGGATNLQ
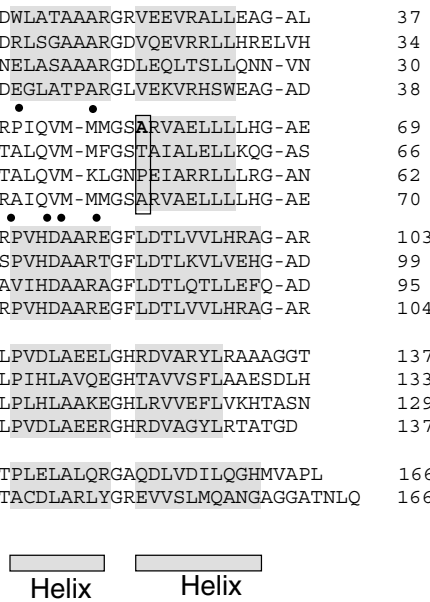

A

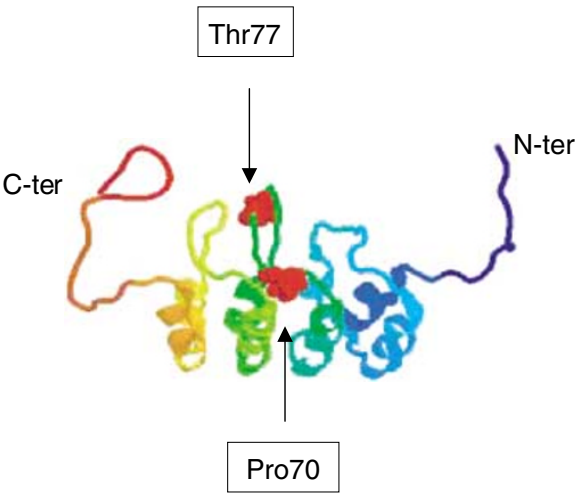

B

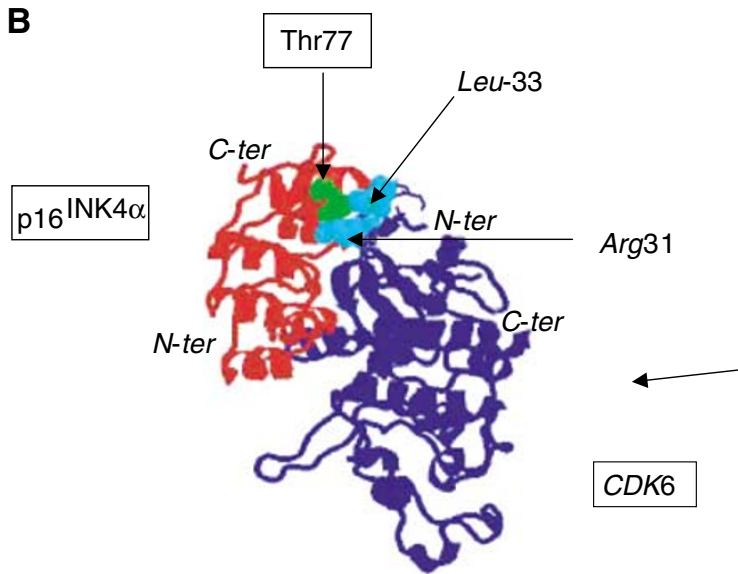

Figure 2 (A) Localisation in the overall $p / 6^{1 \mathrm{NK} 4 a}$ protein structure (PDB $2 A 5 E)$ of the two $p / 6^{I N K 4 a}$ mutants found in FAM2 and FAM3. (B) Localisation of $\mathrm{pl}^{\mathrm{INK} 4 \mathrm{a}}$ Threonine 77 residue in the pl6 $6^{\mathrm{INK} 4 \mathrm{a}}-\mathrm{CDK} 6$ complex (PDB IB|7) and identification of possible partner residues in CDK6.

species, its proximity to the alpha helix of the second ankyrin repeat may place spatial constraints that may be altered with a valine substitution. In addition, it has previously been described as a germline mutation in the case of familial melanoma (Soufir et al, $1998 \mathrm{~b}$ ), and as a somatic mutation in the case of acute lymphoblastic leukaemia (Quesnel et al, 1995), therefore being certainly deleterious.

Three INK4a-ARF changes of uncertain significance were detected in three patients. A $\mathrm{C}>\mathrm{T}$ substitution was found in a young melanoma patient (a woman aged 24 years). This mutation is also localised in INK4a-ARF exon 2, but has no effect on p16 ${ }^{\mathrm{INK} 4 a}$ (Asp105Asp), whereas it induces a C-terminal amino-acid substitution (Arg120Cys) in the $\mathrm{p} 14^{\mathrm{ARF}}$ protein, at a nonconserved codon between human and mice ARF cDNA. A missense mutation in $p 16^{I N K 4 a}$ exon $1 \alpha$ (substitution $\mathrm{G}>\mathrm{A}$ ) was found in a woman who had two distinct melanomas. This novel mutation (Ala5Thr) resides at the $\mathrm{N}$ terminus of the $\mathrm{p} 16^{\mathrm{INK} 4 a}$ protein and has not been previously reported as a polymorphism in any $p 16^{I N K 4 a}$ mutational studies. Finally, a $p 16^{I N K 4 a}$ variant was also found in a 64-year-old man with an NPIM (localised on genital organs). This $\mathrm{C}>\mathrm{T}$ substitution was localised $25 \mathrm{bp}$ upstream from the $p 16^{I N K 4 a}$ initiator translation site and was previously described as a somatic mutation in a skin tumour from a xeroderma pigmentosum patient (Soufir et al, 2000), suggesting that it had a pathogenic role.

Three previously described $p 16^{I N K 4 a}$ polymorphisms were confirmed in this study. Ala148Thr was observed in seven patients $(8 \%)$. This nonsynonymous polymorphism was previously found in $4 \%$ of the Utah population (Kamb et al, 1994), 3\% of $\mathrm{CEPH}$ parents (Hussussian et al, 1994), in $11 \%$ of 131 Australian 
melanoma kindreds (Holland et al, 1999), and was recently excluded as a melanoma/nevus susceptibility allele (Bertram et al, 2002).

The G/C transversion at nucleotide 500 in the $3^{\prime}$ untranslated region (UTR) within exon 3 was identified in 23 of the 89 patients $(26 \%)$. This polymorphism has previously been reported to be present in $11 \%$ of CEPH parents (Ueki et al, 1994), and found to be associated with familial melanoma risk in Queensland (Aitken et al, 1999), but not with sporadic melanomas (Kumar et al, 2001). The $\mathrm{C} / \mathrm{T}$ polymorphism at nucleotide 540 in the $3^{\prime}$ UTR was detected in 14 patients (allelic frequency $8.4 \%$ ), at a frequency lower than the one previously found in sporadic melanoma (14\%) (Kumar et al, 2001).

Sequencing of $C d k 4$ exon 2 failed to detect mutations in the coding sequence in any patient.

\section{INK4a-ARF deletion analysis by real-time quantitative PCR}

Large germline deletions are rare in familial cancers. Nevertheless, a proportion of melanoma families linked to the 9p21 locus do not harbour germline mutations of INK $4 a-A R F$, and three large deletions have been reported in hereditary predisposition to melanoma and nervous system tumours, two involving both $p 16^{I N K 4 a}$ and $p 14^{A R F}$ (Bahuau et al, 1998), and one restricted to exon $1 \beta$ of $p 14^{A R F}$ (Randerson-Moor et al, 2001). Therefore, this suggests that germline lesions of INK $4 a-A R F$ as a genetic mechanism in predisposition to melanoma may need to be reassessed. We therefore investigate $p 16^{I N K 4 a}$ and $p 14^{A R F}$ deletion status by using real-time quantitative PCR. The normalised ratio of each target (exon 3 of $p 16^{I N K 4 a}$, exon $1 \beta$ of $p 14^{A R F}$ ) on $8 \mathrm{q} 11$ SST was close to 1 , indicating that no INK4a-ARF germline deletion was present in any of the 71 patients examined.

\section{DISCUSSION}

To investigate more precisely the role of genetic mechanisms in the aetiology of melanoma, we performed a mutational analysis of $I N K 4 a-A R F$ and $C d k 4$ genes (exon 2) and a deletion analysis of INK $4 a-A R F$ in a series of 89 cases of melanoma with suspected hereditary predisposition. Seven patients $(8 \%)$ had a total of seven different germline changes in INK4a-ARF, in three melanoma kindreds, and four sporadic melanomas (one melanoma associated with a pancreatic cancer, one melanoma occurring before the age of 25 years, one multiple primary melanoma, and one melanoma localised to nonphoto-exposed skin). No mutation was found in exon 2 of $C d k 4$

Three $p 16^{I N K 4 a}$ very likely pathogenic mutations were detected in three out of $23(13 \%)$ melanoma families. This mutational frequency is lower than that previously found in French melanoma families, 48\% (Soufir et al, 1998a). Yet, the inclusion criteria in the former study were much more stringent than in the present one; indeed, melanoma families were selected upon stringent criteria: more than three cases; or two cases in first-degree-related individuals, one of them being below 50 years old, with one additional criterion (multiple primary melanoma in one affected member, pancreatic cancer in the family) (Soufir et al, 1998a). It should be noted that in the present study, INK4a-ARF mutations were found in families comprising, respectively, four, three, and two cases of melanomas. In the latter family (FAM1), the proband developed multiple primary melanomas. No mutations were found in families with second-degree-related affected members. Therefore, our study further confirms that there is a positive correlation between the frequency of INK4a-ARF germline mutation and the strength of family history of melanoma as recently reported (Holland et al, 1999).

One $p 16^{I N K 4 a}$ pathogenic mutation was detected in a patient who had a melanoma associated with a pancreatic cancer, but no family history of melanoma (Table 3). These data confirm that the occurrence of both pancreatic cancer and melanoma, in the same patient, signals an inherited susceptibility to cancer, and that this predisposition is, in some cases, due to germline $p 16^{I N K 4 a}$ mutations (Lal et al, 2000). However, we found no INK4a-ARF mutation in 12 other subjects who had a sporadic melanoma associated with various other cancers. Although our group is too small to draw definitive conclusions, our data are in accordance with a recent report in which no mutation was detected in 27 melanoma patients who also had another cancer (Alao et al, 2002).

Three INK4a-ARF mutations were also found for which an association with a genetic predisposition to melanoma remains uncertain (Table 3), but that were devoid of 100 ADNs ethnically matched controls previously studied (Soufir et al, 1998a). The first one, a novel $p 16^{I N K 4 a}$ missense mutation, was found in one out of $18(5 \%)$ MPM patients. This result could be in agreement with published reports, in which $9.6 \%(3 / 31), 11 \%(2 / 17), 9 \%(9 / 100)$, and $3 \%(2 / 65)$ of MPM patients were carriers of INK4a-ARF germline mutations (MacKie et al, 1998; Monzon et al, 1998; Hashemi et al, 2000; Auroy et al, 2001). However, Ala5Thr is most likely a polymorphism as the amino terminus of $\mathrm{p} 16^{\mathrm{INK} 4 a}$ prior to the start of the ankyrin repeats is poorly conserved and is believed to have no effect on the stability of $16^{\mathrm{INK} 4 a}$. Nevertheless, it has recently been shown that some $\mathrm{p} 16^{\mathrm{INK} 4 a}$ mutants failed to induced growth arrest despite retaining normal binding to CDK4 (Becker et al, 2001), suggesting that $p 16^{I N K 4 a}$ mutations outside the ankyrins motifs may confer a predisposition to melanoma through a mechanism not yet identified.

The second variant affects only the $\mathrm{p} 14^{\mathrm{ARF}}$ reading frame and was found in one of $21(5 \%)$ young melanoma patients without a family history of melanoma. To date, $p 16^{I N K 4 a}$ germline mutations were characterised in only two out of $55 \mathrm{MM}$ patients less than 30 years, but that both had a history of familial melanoma (Whiteman et al, 1997; Tsao et al, 2000). Together with our data, this shows that the INK4a-ARF gene is rarely involved in genetic predisposition to melanoma in young patients with no familial history of melanoma. However, in the present case, a pathogenic effect of this mutation is suggested by several data. Specific $p 14^{A R F}$ germline defects were previously reported in a family with melanoma and neural tumours and in a patient with multiple melanomas (Randerson-Moor et al, 2001; Rizos et al, 2001b). In addition, some of the INK4a-ARF germline mutations found in melanomaprone families have been shown to affect $\mathrm{p} 14^{\mathrm{ARF}}$ function (Rizos et al, 2001a). Our mutation lies within the C-terminal p14 ${ }^{\mathrm{ARF}}$ nucleolar localisation domain, which is essential for full $\mathrm{p} 14^{\mathrm{ARF}}$ activity (Rizos et al, 2000). On the other hand, this mutation lies at a nonconserved codon between mice and human ARF protein, and therefore, may be a rare nonpathogenic variant.

The third variant is a $p 16^{I N K 4 a}$ substitution located $25 \mathrm{bp}$ upstream of the ATG, in the p16 ${ }^{\mathrm{INKa}} 5^{\prime}$ UTR and was detected in one of 14 patients with an NPIM. Germline mutations in critical regions of the $\mathrm{p} 16^{\mathrm{INKa}}$ promoter could reduce or abolish promoter function, resulting in a genetic predisposition to disease. Yet, to date, only three variants localised in the $5^{\prime} \mathrm{UTR}$ of $16^{\mathrm{INKa}}$ $(-14 \mathrm{C}>\mathrm{T},-33 \mathrm{G}>\mathrm{C},-34 \mathrm{G}>\mathrm{A})$ have been characterised in melanoma patients (Liu et al, 1999) (Hashemi et al, 2000) (Auroy et al, 2001), of which only the latter one has a proved functional effect (Liu et al, 1999). This particular mutation localised $34 \mathrm{bp}$ upstream from the ATG translation initiation codon, creates an aberrant initiation codon, and has been detected in two MPM patients and in two melanoma families. In our case, it should be noted that the $-25 \mathrm{C}>\mathrm{T}$ substitution was previously found in a skin squamous carcinoma from a xeroderma pigmentosum patient (Soufir et al, 2000), suggesting that it could be pathogenic. On the other hand, this mutation was not observed in a mutational screening of the p16 $6^{\mathrm{INKa}}$ promoter in 109 melanoma families (Harland et al, 2000), therefore raising the possibility of a rare polymorphism, and indicating the need for functional studies of 
p16 ${ }^{\mathrm{INKa}}$ expression in order to determine whether or not promoter single-nucleotide polymorphisms are pathogenic.

No germline mutation of $C d k 4$ exon 2 was detected in any melanoma patient. This confirms previous studies performed in melanoma families (Goldstein et al, 2002), and further shows that the $C d k 4$ gene is very rarely involved in genetic predisposition to melanoma.

We found no germline deletion of the INK4a-ARF locus in 71 melanoma patients, indicating that constitutional inactivation of this locus by deletion is not a frequent mechanism in genetic predisposition to melanoma.

In conclusion, our study confirms that germline mutations of the INK4a-ARF gene are predominantly involved in genetic predisposition to familial melanoma, particularly in large multicase melanoma families or in families comprising a member affected with multiple melanomas. Other conditions, despite suggesting a genetic predisposition to melanoma, rarely show INK4a-ARF germline mutations. Our findings are in accordance with the Melanoma Genetics Consortium, which considers that melanoma patients with or without stringent familial criteria should not be tested outside of defined research protocols (Kefford et al, 1999, 2002).

\section{REFERENCES}

Aitken J, Welch J, Duffy D, Milligan A, Green A, Martin N, Hayward N (1999) CDKN2A variants in a population-based sample of Queensland families with melanoma. J Natl Cancer Inst 91: 446-452

Alao JP, Mohammed MQ, Retsas S (2002) The CDKN2A tumour suppressor gene: no mutations detected in patients with melanoma and additional unrelated cancers. Melanoma Res 12: 559-563

Ashcroft M, Vousden KH (1999) Regulation of p53 stability. Oncogene 18: $7637-7643$

Auroy S, Avril MF, Chompret A, Pham D, Goldstein AM, Bianchi-Scarra G, Frebourg T, Joly P, Spatz A, Rubino C, Demenais F, Bressac-de Paillerets B (2001) Sporadic multiple primary melanoma cases: CDKN2A germline mutations with a founder effect. Genes Chromosomes Cancer 32: $195-202$

Bahuau M, Vidaud D, Jenkins RB, Bieche I, Kimmel DW, Assouline B, Smith JS, Alderete B, Cayuela JM, Harpey JP, Caille B, Vidaud M (1998) Germ-line deletion involving the INK4 locus in familial proneness to melanoma and nervous system tumors. Cancer Res 58: 2298-2303

Bastiaens M, ter Huurne J, Gruis N, Bergman W, Westendorp R, Vermeer BJ, Bavinck JN (2001) The melanocortin-1-receptor gene is the major freckle gene. Hum Mol Genet 10: 1701-1708

Becker TM, Rizos H, Kefford RF, Mann GJ (2001) Functional impairment of melanoma-associated p16(INK4a) mutants in melanoma cells despite retention of cyclin-dependent Kinase 4 binding. Clin Cancer Res 7: $3282-3288$

Bertin R, Acquaviva C, Mirebeau D, Guidal-Giroux C, Vilmer E, Cave H (2003) CDKN2A, CDKN2B, and MTAP gene dosage permits precise characterization of mono- and bi-allelic 9p21 deletions in childhood acute lymphoblastic leukemia. Genes Chromosomes Cancer 37: 44-57

Bertram CG, Gaut RM, Barrett JH, Pinney E, Whitaker L, Turner F, Bataille V, Dos Santos Silva I, A JS, Bishop DT, Newton Bishop JA (2002) An assessment of the CDKN2A variant Ala148Thr as a nevus/melanoma susceptibility allele. J Invest Dermatol 119: 961-965

Borg A, Sandberg T, Nilsson K, Johannsson O, Klinker M, Masback A, Westerdahl J, Olsson H, Ingvar C (2000) High frequency of multiple melanomas and breast and pancreas carcinomas in CDKN2A mutationpositive melanoma families. J Natl Cancer Inst 92: 1260-1266

Dilworth D, Liu L, Stewart AK, Berenson JR, Lassam N, Hogg D (2000) Germline CDKN2A mutation implicated in predisposition to multiple myeloma. Blood 95: 1869-1871

Flores JF, Pollock PM, Walker GJ, Glendening JM, Lin AH, Palmer JM, Walters MK, Hayward NK, Fountain JW (1997) Analysis of the CDKN2A CDKN2B and CDK4 genes in 48 Australian melanoma kindreds. Oncogene 15: 2999-3005

Ginzinger DG (2002) Gene quantification using real-time quantitative PCR: an emerging technology hits the mainstream. Exp Hematol 30: 503-512
Besides these major melanoma-predisposing genes, other genetic predisposition factors exist. Firstly, polygenic inheritance in combination with environmental factors such as high sun exposure has been shown in several studies, depending upon polymorphisms located on genes controlling DNA repair (Winsey et al, 2000), pigmentation (Palmer et al, 2000), and reactive oxygen detoxification pathways (Strange et al, 1999; Kanetsky et al, 2001). Among these, loss of function variants of the human melanocortin1 receptor gene, which plays a crucial role in pigmentation (Valverde et al, 1995; Bastiaens et al, 2001), seems to have an important role in determining melanoma risk (Palmer et al, 2000; Kennedy et al, 2001). Secondly, the possibility of mutations in additional, as yet unidentified highly penetrant melanoma-predisposing genes is still a research tool.

\section{ACKNOWLEDGEMENTS}

This work was supported by grants from L'Assistance Publique des Hôpitaux de Paris (AP-HP, Contract Grant number: CRC00128) and from La Société Française de Dermatologie (SFD).

Goldstein AM, Chidambaram A, Halpern A, Holly EA, Guerry ID, Sagebie R, Elder DE, Tucker MA (2002) Rarity of CDK4 germline mutations in familial melanoma. Melanoma Res 12: 51 - 55

Goldstein AM, Fraser MC, Struewing JP, Hussussian CJ, Ranade K, Zametkin DP, Fontaine LS, Organic SM, Dracopoli NC, Clark Jr WH, Tucker MA (1995) Increased risk of pancreatic cancer in melanomaprone kindreds with p16INK4 mutations [see comments]. $N$ Engl J Med 333: $970-974$

Greene MH (1999) The genetics of hereditary melanoma and nevi. 1998 update. Cancer 86: 2464-2477

Guldberg P, Kirkin AF, Gronbaek K, thor Straten P, Ahrenkiel V, Zeuthen J (1997) Complete scanning of the CDK4 gene by denaturing gradient gel electrophoresis: a novel missense mutation but low overall frequency of mutations in sporadic metastatic malignant melanoma. Int J Cancer 72: $780-783$

Harland M, Holland EA, Ghiorzo P, Mantelli M, Bianchi-Scarra G, Goldstein AM, Tucker MA, Ponder BA, Mann GJ, Bishop DT, Newton Bishop J (2000) Mutation screening of the CDKN2A promoter in melanoma families. Genes Chromosomes Cancer 28: $45-57$

Harland M, Meloni R, Gruis N, Pinney E, Brookes S, Spurr NK, Frischauf AM, Bataille V, Peters G, Cuzick J, Selby P, Bishop DT, Bishop JN (1997) Germline mutations of the CDKN2 gene in UK melanoma families. Hum Mol Genet 6: $2061-2067$

Hashemi J, Platz A, Ueno T, Stierner U, Ringborg U, Hansson J (2000) CDKN2A germ-line mutations in individuals with multiple cutaneous melanomas. Cancer Res 60: 6864-6867

Hayward N (2000) New developments in melanoma genetics. Curr Oncol Rep 2: 300-306

Holland EA, Schmid H, Kefford RF, Mann GJ (1999) CDKN2A (P16(INK4a)) and CDK4 mutation analysis in 131 Australian melanoma probands: effect of family history and multiple primary melanomas. Genes Chromosomes Cancer 25: 339-348

Hussussian CJ, Struewing JP, Goldstein AM, Higgins PA, Ally DS, Sheahan MD, Clark Jr WH, Tucker MA, Dracopoli NC (1994) Germline p16 mutations in familial melanoma. Nat Genet 8: 15-21

Kamb A, Shattuck-Eidens D, Eeles R, Liu Q, Gruis NA, Ding W, Hussey C, Tran T, Miki Y, Weaver-Feldhaus J et al. (1994) Analysis of the p16 gene (CDKN2) as a candidate for the chromosome 9p melanoma susceptibility locus. Nat Genet 8: 23-26

Kamijo T, Zindy F, Roussel MF, Quelle DE, Downing JR, Ashmun RA, Grosveld G, Sherr CJ (1997) Tumor suppression at the mouse INK4a locus mediated by the alternative reading frame product p19ARF. Cell 91: $649-659$

Kanetsky PA, Holmes R, Walker A, Najarian D, Swoyer J, Guerry D, Halpern A, Rebbeck TR (2001) Interaction of glutathione $S$-transferase 
M1 and T1 genotypes and malignant melanoma. Cancer Epidemiol Biomarkers Prev 10: 509-513

Kato T, Suetake T, Sugiyama Y, Tabata N, Tagami H (1996) Epidemiology and prognosis of subungual melanoma in 34 Japanese patients. $\mathrm{Br} J$ Dermatol 134: 383 - 387

Kefford R, Bishop JN, Tucker M, Bressac-de Paillerets B, Bianchi-Scarra G, Bergman W, Goldstein A, Puig S, Mackie R, Elder D, Hansson J, Hayward N, Hogg D, Olsson H (2002) Genetic testing for melanoma. Lancet Oncol 3: $653-654$

Kefford RF, Newton Bishop JA, Bergman W, Tucker MA (1999) Counseling and DNA testing for individuals perceived to be genetically predisposed to melanoma: a consensus statement of the melanoma genetics consortium. J Clin Oncol 17: 3245-3251

Kennedy C, ter Huurne J, Berkhout M, Gruis N, Bastiaens M, Bergman W, Willemze R, Bouwes Bavinck JN (2001) Melanocortin 1 receptor (MC1R) gene variants are associated with an increased risk for cutaneous melanoma which is largely independent of skin type and hair color. $J$ Invest Dermatol 117: 294-300

Kumar R, Smeds J, Berggren P, Straume O, Rozell BL, Akslen LA, Hemminki K (2001) A single nucleotide polymorphism in the $3^{\prime}$ untranslated region of the CDKN2A gene is common in sporadic primary melanomas but mutations in the CDKN2B, CDKN2C, CDK4 and p53 genes are rare. Int J Cancer 95: 388-393

Lal G, Liu L, Hogg D, Lassam NJ, Redston MS, Gallinger S (2000) Patients with both pancreatic adenocarcinoma and melanoma may harbor germline CDKN2A mutations. Genes Chromosomes Cancer 27: 358-361

Liu L, Dilworth D, Gao L, Monzon J, Summers A, Lassam N, Hogg D (1999) Mutation of the CDKN2A $5^{\prime}$ UTR creates an aberrant initiation codon and predisposes to melanoma. Nat Genet 21: 128-132

MacKie RM, Andrew N, Lanyon WG, Connor JM (1998) CDKN2A germline mutations in UK patients with familial melanoma and multiple primary melanomas. I Invest Dermatol 111: 269-272

Miller SA, Dykes DD, Polesky HF (1988) A simple salting out procedure for extracting DNA from human nucleated cells. Nucleic Acids Res 16: 1215

Monzon J, Liu L, Brill H, Goldstein AM, Tucker MA, From L, McLaughlin J, Hogg D, Lassam NJ (1998) CDKN2A mutations in multiple primary melanomas. N Engl J Med 338: 879-887

Palmer JS, Duffy DL, Box NF, Aitken JF, O'Gorman LE, Green AC, Hayward NK, Martin NG, Sturm RA (2000) Melanocortin-1 receptor polymorphisms and risk of melanoma: is the association explained solely by pigmentation phenotype? Am J Hum Genet 66: 176-186

Piepkorn M (2000) Melanoma genetics: an update with focus on the CDKN2A(p16)/ARF tumor suppressors. J Am Acad Dermatol 42: $705-$ 722 quiz $723-726$

Pomerantz J, Schreiber-Agus N, Liegeois NJ, Silverman A, Alland L, Chin L, Potes J, Chen K, Orlow I, Lee HW, Cordon-Cardo C, DePinho RA (1998) The Ink4a tumor suppressor gene product, p19Arf, interacts with MDM2 and neutralizes MDM2's inhibition of p53. Cell 92: 713-723

Quesnel B, Preudhomme C, Philippe N, Vanrumbeke M, Dervite I, Lai JL, Bauters F, Wattel E, Fenaux P (1995) p16 gene homozygous deletions in acute lymphoblastic leukemia. Blood 85: 657-663

Randerson-Moor JA, Harland M, Williams S, Cuthbert-Heavens D, Sheridan E, Aveyard J, Sibley K, Whitaker L, Knowles M, Bishop JN, Bishop DT (2001) A germline deletion of p14(ARF) but not CDKN2A in a melanoma-neural system tumour syndrome family. Hum Mol Genet 10: $55-62$

Rizos H, Darmanian AP, Holland EA, Mann GJ, Kefford RF (2001a) Mutations in the INK4a/ARF melanoma susceptibility locus functionally impair p14ARF. J Biol Chem 276: 41424-41434

Rizos H, Darmanian AP, Mann GJ, Kefford RF (2000) Two arginine rich domains in the p14ARF tumour suppressor mediate nucleolar localization. Oncogene 19: 2978-2985

Rizos H, Puig S, Badenas C, Malvehy J, Darmanian AP, Jimenez L, Mila M, Kefford RF (2001b) A melanoma-associated germline mutation in exon 1beta inactivates p14ARF. Oncogene 20: $5543-5547$
Russo AA, Tong L, Lee JO, Jeffrey PD, Pavletich NP (1998) Structural basis for inhibition of the cyclin-dependent kinase Cdk6 by the tumour suppressor p16INK4a. Nature 395: 237-243

Saida T (2001) Recent advances in melanoma research. J Dermatol Sci 26: $1-13$

Sherr CJ (2000) The Pezcoller lecture: cancer cell cycles revisited. Cancer Res 60: $3689-3695$

Simon M, Koster G, Menon AG, Schramm J (1999) Functional evidence for a role of combined CDKN2A (p16-p14(ARF))/CDKN2B (p15) gene inactivation in malignant gliomas. Acta Neuropathol (Berl) 98: $444-452$

Soufir N, Avril MF, Chompret A, Demenais F, Bombled J, Spatz A, StoppaLyonnet D, Benard J, Bressac-de Paillerets B (1998a) Prevalence of p16 and CDK4 germline mutations in 48 melanoma-prone families in France. The French Familial Melanoma Study Group. Hum Mol Genet 7: $209-216$

Soufir N, Avril MF, Chompret A, Demenais F, Bombled J, Spatz A, StoppaLyonnet D, Benard J, Bressac-de Paillerets B (1998b) Prevalence of p16 and CDK4 germline mutations in 48 melanoma-prone families in France. The French Familial Melanoma Study Group [published erratum appears in Hum Mol Genet 1998 May;7(5):941]. Hum Mol Genet 7: 209-216

Soufir N, Daya-Grosjean L, de La Salmoniere P, Moles JP, Dubertret L, Sarasin A, Basset-Seguin N (2000) Association between INK4a-ARF and p53 mutations in skin carcinomas of xeroderma pigmentosum patients. $J$ Natl Cancer Inst 92: $1841-1847$

Strange RC, Ellison T, Ichii-Jones F, Bath J, Hoban P, Lear JT, Smith AG, Hutchinson PE, Osborne J, Bowers B, Jones PW, Fryer AA (1999) Cytochrome P450 CYP2D6 genotypes: association with hair colour, Breslow thickness and melanocyte stimulating hormone receptor alleles in patients with malignant melanoma. Pharmacogenetics 9: $269-276$

Tsao H, Zhang X, Kwitkiwski K, Finkelstein DM, Sober AJ, Haluska FG (2000) Low prevalence of germline CDKN2A and CDK4 mutations in patients with early-onset melanoma. Arch Dermatol 136: 1118-1122

Ueki K, Rubio MP, Ramesh V, Correa KM, Rutter JL, von Deimling A, Buckler AJ, Gusella JF, Louis DN (1994) MTS1/CDKN2 gene mutations are rare in primary human astrocytomas with allelic loss of chromosome 9p. Hum Mol Genet 3: $1841-1845$

Valverde P, Healy E, Jackson I, Rees JL, Thody AJ (1995) Variants of the melanocyte-stimulating hormone receptor gene are associated with red hair and fair skin in humans. Nat Genet 11: 328-330

Walker GJ, Hussussian CJ, Flores JF, Glendening JM, Haluska FG, Dracopoli NC, Hayward NK, Fountain JW (1995) Mutations of the CDKN2/p16INK4 gene in Australian melanoma kindreds. Hum Mol Genet 4: $1845-1852$

Whiteman DC, Milligan A, Welch J, Green AC, Hayward NK (1997) Germline CDKN2A mutations in childhood melanoma. J Natl Cancer Inst 89: 1460

Winsey SL, Haldar NA, Marsh HP, Bunce M, Marshall SE, Harris AL, Wojnarowska F, Welsh KI (2000) A variant within the DNA repair gene XRCC3 is associated with the development of melanoma skin cancer. Cancer Res 60: $5612-5616$

Yang CT, You L, Yeh CC, Chang JW, Zhang F, McCormick F, Jablons DM (2000) Adenovirus-mediated p14(ARF) gene transfer in human mesothelioma cells. J Natl Cancer Inst 92: 636-641

Yarbrough WG, Aprelikova O, Pei H, Olshan AF, Liu ET (1996) Familial tumor syndrome associated with a germline nonfunctional p16INK4a allele. J Natl Cancer Inst 88: 1489-1491

Zhuang SM, Schippert A, Haugen-Strano A, Wiseman RW, Soderkvist P (1998) Inactivations of p16INK4a-alpha, p16INK4a-beta and p15INK4b genes in $2^{\prime}, 3^{\prime}$-dideoxycytidine- and 1,3-butadiene-induced murine lymphomas. Oncogene 16: 803-808

Zuo L, Weger J, Yang Q, Goldstein AM, Tucker MA, Walker GJ, Hayward N, Dracopoli NC (1996) Germline mutations in the p16INK4a binding domain of CDK4 in familial melanoma. Nat Genet 12: 97-99 